\title{
MAPPING OF DEBRIS FLOWS BY THE MORPHOMETRIC ANALYSIS OF DTM: A CASE STUDY OF THE VRÁTNA DOLINA VALLEY, SLOVAKIA
}

\author{
Marek Fraštia*, Pavel Liščák**, Andrej Žilka**, Peter Pauditš**, \\ Peter Bobál***, Stano Hronček****, Slavomír Sipina***, Pavol Ihring****, \\ Marián Marčiš* \\ * STU Bratislava, Faculty of Civil Engineering, Radlinského 11, 81005 Bratislava 1, Slovak Republic, \\ marek.frastia@stuba.sk,marian.marcis@stuba.sk \\ ** State Geological Institute of Dionýz Štúr, Mlynská dolina 1, 81704 Bratislava 11, Slovak Republic, \\ pavel.liscak@geology.sk, andrej.zilka@gmail.com, peter.paudits@geology.sk \\ *** YMS, a. s. Hornopotočná 1, 91701 Trnava, Slovak Republic, \\ peter.bobal@yms.sk, slavomir.sipina@yms.sk \\ **** Proxima R\&D s.r.o., Na pažiti 273/8, 90021 Svätý Jur, Slovak Republic, \\ shroncek@gmail.com,pauli@geoproxima.sk
}

\begin{abstract}
Mapping of debris flows by the morphometric analysis of DTM: a case study of the Vrátna dolina Valley, Slovakia

The main objective of this contribution is to detect the morphogenetic processes by the numerical method of the differential geometry technique and compare the results with field surveying. The area of interest, the Vrátna dolina Valley, is located in the Malá Fatra Mountains in the northern part of Slovakia. Extensive mass movement deformations occurred in the surveyed area in 2014 induced by extreme precipitation events caused considerable damage. The Proxima software technology has been used to identify terrain elements using a precise digital terrain model (DTM) for the localisation of the debris flows head scarps. Precise DTM was derived from the airborne laser scanning (ALS) data. The morphometric analysis of landslide area was carried out on four selected locations. Verification of numerical mapping was performed by comparing results to the field survey data through visual comparison and area computation. Supplementary data was used in the form of orthophoto mosaics. The used spatial analysis applied on ALS data shows a high coincidence with the detection of the head scarps by field surveying, particularly in the hard to access and afforested areas. The main advantage of this approach lies in the reduction of field surveying and in the possible detection of the terrain changes not found during field surveying.
\end{abstract}

Key words: debris flow, airborne laser scanning, morphometric analysis, Vrátna dolina Valley, Slovakia

\section{INTRODUCTION}

Slope deformations can significantly affect, not only the character and state of landscape, but they can also cause damage to property and, in the worst case, loss to human life. During precipitation events of higher than normal intensity, extensive mass movements can occur such as slides, debris flows and rockfall, particularly in mountainous areas. In order to avoid greater damage in the areas concerned, it is essential to keep them constantly monitored and to implement adequate measures. The identification of the affected areas is therefore a key task in avoiding events of this nature. For this reason, several types of technologies have been developed to identify vulnerable and affected sites (Schraml et al. 2015).

One of the most appropriate options for the inventory and monitoring of land affected with slope deformation is the use of airborne laser scanning technology (Jaboyedoff et al. 2010 and Bollman et al. 2011) and photogrammetry. ALS 
(airborne laser scanning) penetrates well through vegetation, allowing detection of the Earth's surface itself, including slope failures. Photogrammetry, on the other hand, provides photorealistic textural and spectral information projected into orthophoto maps based on a detailed 3D model of terrain and objects generated from images (Gonzáles-Díez et al. 2013, Honkavaara 2013 and White et al. 2013) but photogrammetry methods are not suitable for DTM in forests (Pavelka and Šedina 2015). ALS data provides a suitable basis for the mapping of slope processes, especially in terrain, which is difficult to access by humans such as wooded mountain areas (Vastaranta et al. 2013). The narrow beam divergence of a laser allows the accurate measurement of a 3-D position also under tree canopy in the case where a portion of the laser energy penetrates through the crown. As a result of the scanning process and subsequent data processing (filtration and classification), we can get point cloud from which the terrain surface can be modelled. From this data, it is possible to generate a digital terrain model and then use it as the basis for the identification of the morphogenetic processes or other phenomena in the territory. Evaluation of the accuracy of DTM obtained from laser scanning data is given in many publications. DTM accuracy expressed through the root mean square error (RMSE) can be reached in the ideal condition value of $0.10 \mathrm{~m}$. Reported accuracies vary between $0.10 \mathrm{~m}$ and $2 \mathrm{~m}$. They depend on many factors like point density, vegetation density, interpolation method, etc. (Pfeifer et al. 2001, Shan and Toth 2009, Vosselman and Maas 2010 and Razak et al. 2011).

To obtain adequate outputs of slope deformation geometry from DTM, it is important to select a suitable method. At present, there are a number of methods that can be used to identify slope deformations from DTM in the landscape. These methods can be based just on the visual interpreting of digital terrain models or can use different surface analysis to derive morphometric parameters, which provide additional information for the identification of slope deformations.

The visual interpretation of the DTM is based on the use of various visualization techniques. Most often, shaded relief or terrain visualization using variations in elevations are used. The shaded relief gives the possibility of better emphasizing the terrain elements and thus contributes to a more precise identification of the slides. To avoid the loss of information, the shaded relief from different azimuths or angles of illumination is used (Razak et al. 2011 and Bobal et al. 2017). Analyses over the digital relief model provide the possibility to derive different morphometric characteristics. The analyses of this type are already available in commonly used GIS applications. An example is, for instance, the analysis of relief curvature, slope or surface roughness calculation. However, the method of deriving morphometric parameters may vary in different applications. Thanks to the morphometric characteristics thus obtained, it is then possible to localize the terrain distortions (Mitášová and Hofierka 1993, Roberts 2001, Ardizzone 2007 and Dlugosz 2012).

The aim of this contribution was to identify slope deformations in four selected localities in the Vrátna dolina Valley after the occurrence of an extreme collision event. As input data, a digital terrain model was created using airborne laser scanning data.

The Proxima technology has been used to identify slope deformations, providing a different approach compared to conventional methods. The results were compared with data obtained by a field survey. 


\section{STUDY AREA AND DEBRIS FLOWS IN 2014}

The Vrátna dolina Valley is situated in northern part of Slovakia in the Malá Fatra Mountains, Kriván̆ part (Fig. 1). The whole valley is oriented north-south direction on the north side of the mountain chain and it is long about $7 \mathrm{~km}$ from the beginning at the Terchová municipality up to the mountain ridge. The study area is located in the highest parts of the valley and it is divided into the 4 smaller test regions. The extent of the study area is $8 \mathrm{~km}^{2}$ (Fig. 1).

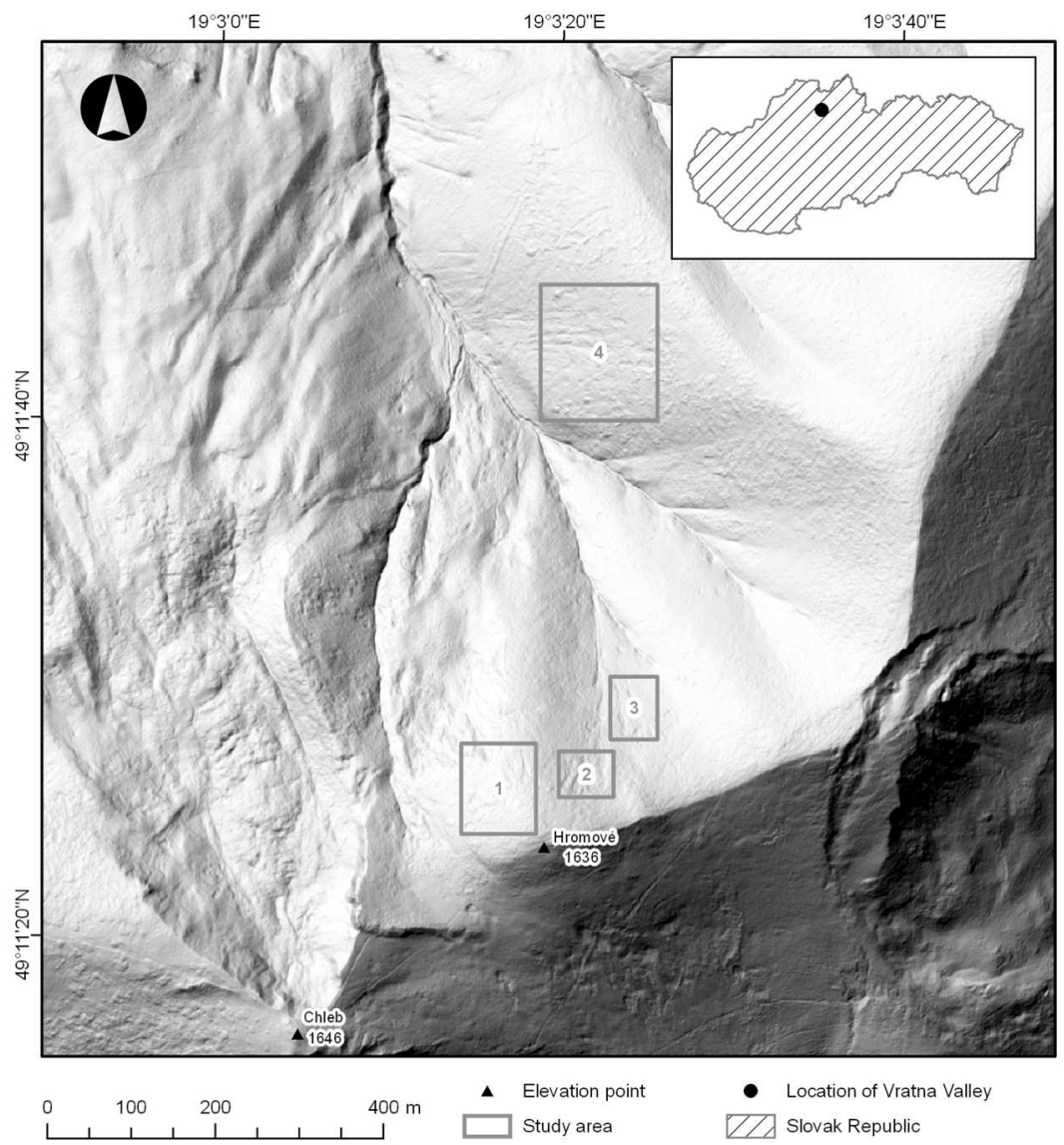

Fig. 1. Study area and tested localities

In the geological setting of the area Tatricum and Fatricum rocks are present. The greater part of the landslides and their head scarps land were located mainly in the youngest rocks of the Fatricum sequence (Tithonian - Neocomian marly limestone of the Mráznica Formation) with an inclination of $25^{\circ}-35^{\circ}$; in general from the $\mathrm{W}$ up to $\mathrm{N}$.

The Quaternary sediments are represented by colluvial sediments of varied lithological composition from rocky debris through loamy stone rubble up to deluvial 
loams. In fact, colluvial sediments cover the major part of the area, their thicknesses, however, generally do not exceed $2 \mathrm{~m}$. Engineering geological conditions of the territory are derived from the geological setting. Formerly it had been postulated that the northern slopes of the Chleb Mt. represent a glacier cirque of fan-shaped form. Nemčok (1973) recognized that the northern flank of the Chleb Mt. is a slope deformation in the form of a rock slide along predisposed stratification planes (Fig. 2). The maximum length of rock accumulation is $1,400 \mathrm{~m}$ (NS), the maximum width is $700 \mathrm{~m}(\mathrm{EW})$, the maximum thickness is about $30-50 \mathrm{~m}$.

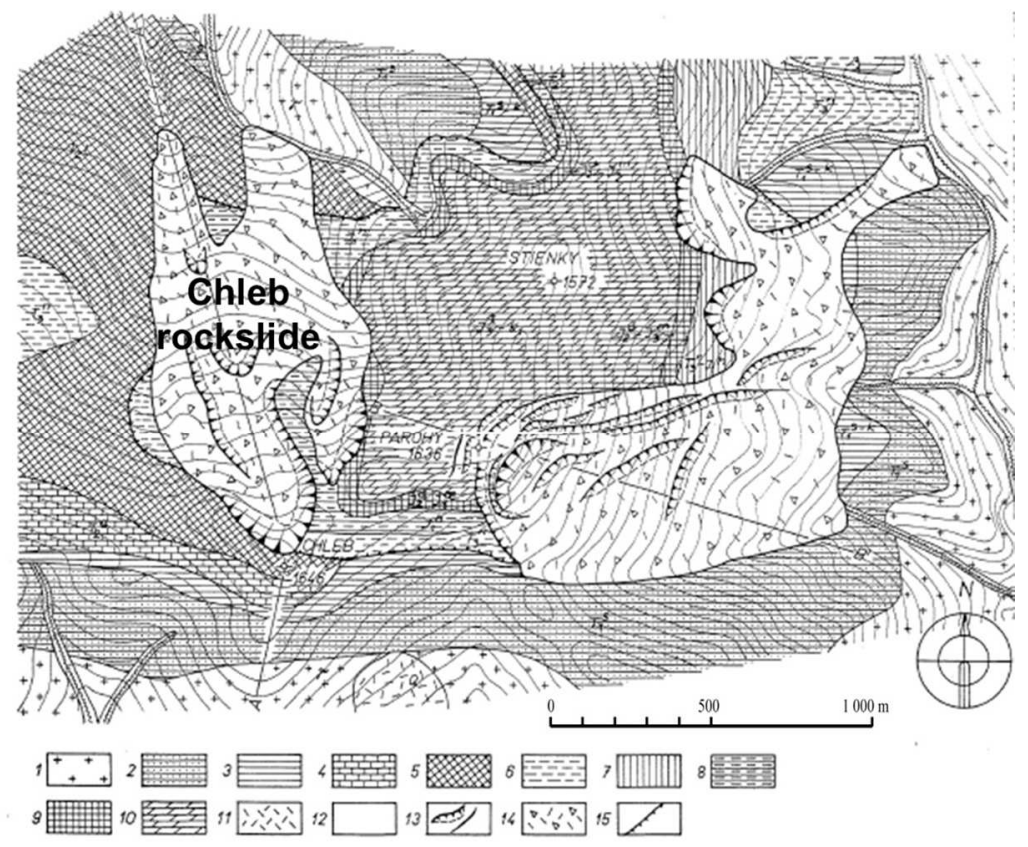

Fig. 2. Rockslide on the northern slope of the Chleb Mt.

1 - autometamorphosed biotite and two-mica granites (Palaeozoic), 2 - quartzites (Early Triassic), 3 - marly shales and limestones (Campilian), 4 - grey limestones (Anisian), 5 - dolomites (Ladinian), 6 - variegated shales (Norian), 7 - dark shales organogenic Lumachella limestones (Rhaetian-Hettangian), 8 - dark-grey marlstones and limestones, cherts, crinoidal limestones (Early Jurassic), 9 - red radiolarian limestones (Dogger-Malm), 10 - grey marlstones and marly limestones (Tithonian - Aptian; Neocomian), 11 - colluvial deposits, 12 - fluvial deposits, 13 - scarps, crevasses, 14 - stone accumulations, 15 - overthrust plane; (modified after Baliak et al. 1981)

The altitude difference between the head scarp and toe of the rockslide is 600 $\mathrm{m}$. In the head scarp two main horseshoe-shaped escarpments have formed. One of them reaches to the Chleb summit and strongly violates its original dome shape. The maximum height of escarpment rock walls is $50 \mathrm{~m}$ (Fig. 3). Sliding, or the collapse of Jurassic limestone rock masses took place along the shale strata of the Carpathian Keuper (Upper Triassic). General stratification is $30-40^{\circ}$ to the North, thus down the slope. As in dozens of cases in the Mesozoic mountains of Slovakia, the rigid, tectonically broken blocks of Jurassic limestone, lying on plastic Keuper shale strata, have induced the formation of slow creep deformation, which over time has transformed into a large-scale rockslide (Fig. 4). 
Colluvial deposits are characterized by a large lithological variability depending on the basement rock. Loamy-stony and clayey deluvia are developed on marl sediments of the Mráznica Fm. Debris flows were activated in these deluvial sediments below the ridge of about $1600-1500 \mathrm{~m}$ a.s.l. (Fig. 5).

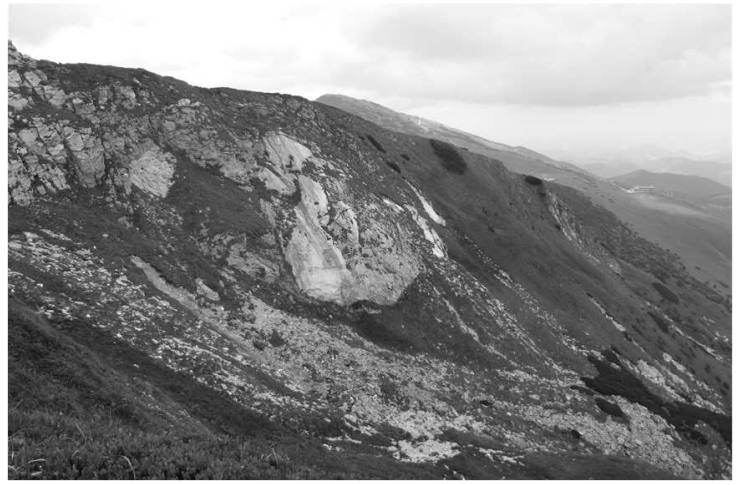

Fig. 3. Head scarp below the Chleb Mt. summit on the north side

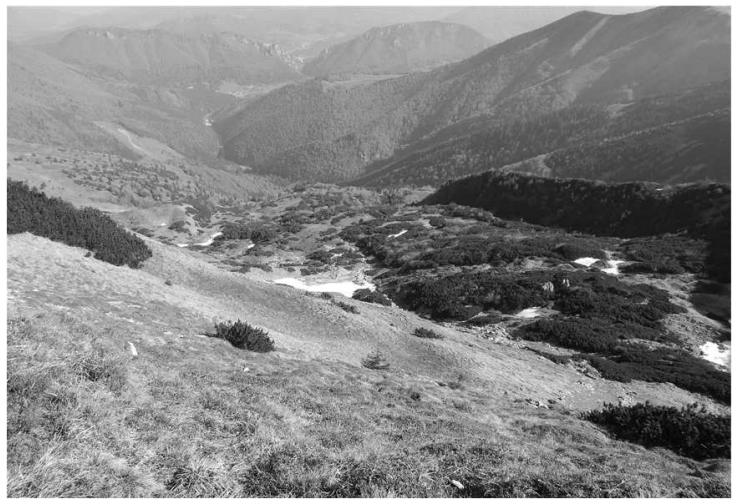

Fig. 4. Rockslide on the northern flanks of the Chleb Mt.

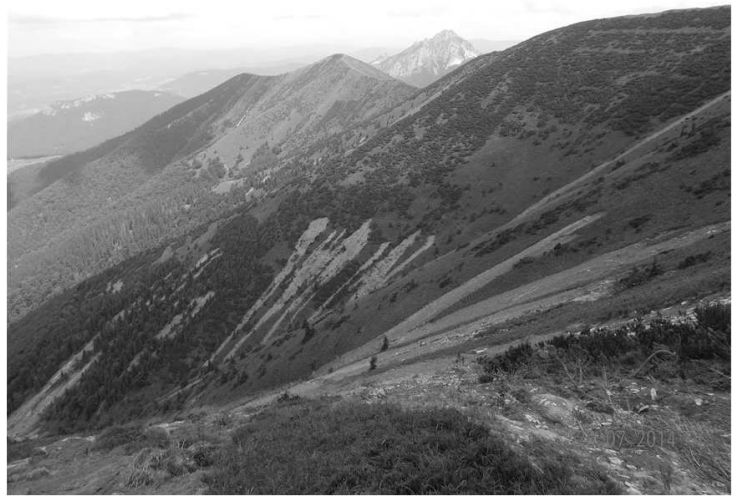

Fig. 5. Head scarps of debris flows below the Hromové Ridge (northern flanks) 
The debris flows in Vrátna dolina Valley, along with accompanying landslides, were formed on Monday, 21. 07. 2014 between 15:00 and 18:00h due to the precipitation anomalies (according to the Slovak Hydrometeorological Institute station in Vrátna, the amount of precipitation reached $67 \mathrm{~mm}$ within 3 hours). After the computation of the maximum radar reflectivity to rainfall intensity it was found that within the first wave of precipitation (between 15:15 and 15:55), it dropped by about 40mm. In the second wave (between 15:55 and 16:55), about $50 \mathrm{~mm}$ of precipitation was recorded; thus, within $100 \mathrm{~min}$ about $90 \mathrm{~mm}$ of rain $\left(901 . \mathrm{m}^{-2}\right)$ must have occurred (Liová et al. 2015). As a consequence a flood situation followed down the valley, in the Terchová municipality. The Mayor of Terchová declared an emergency situation on 23. 07. 2014 at 15:30. Many streets were cut off from supplies, medical assistance, roads and bridges were damaged by flooding, along with 50 cars and the cable line station.

The slope movements along the planar slip surface were induced by the favourable inclination of bedding/foliation. Within the detachment areas of these landslides of rather small thickness broke away quite small, but numerous "plates" of sliding material (with an area of several hundred $\mathrm{m}^{2}$ ), which generally moved at a speed of several meters per second, preferentially down existing avalanche chutes, often above strongly wetted vegetation cover (grass and blueberries).

Approximately 800 meters from the lower lift station of Vrátna, the thickness of a rolling mass of water-rock-earth-trees was measured on upright trees (Fig. 6). It seems that the thickness of the flow here reached up to $2 \mathrm{~m}$. A creek with the depth of a mere $20 \mathrm{~cm}$ flowed there at the time of inspection (July 28th, 2014).

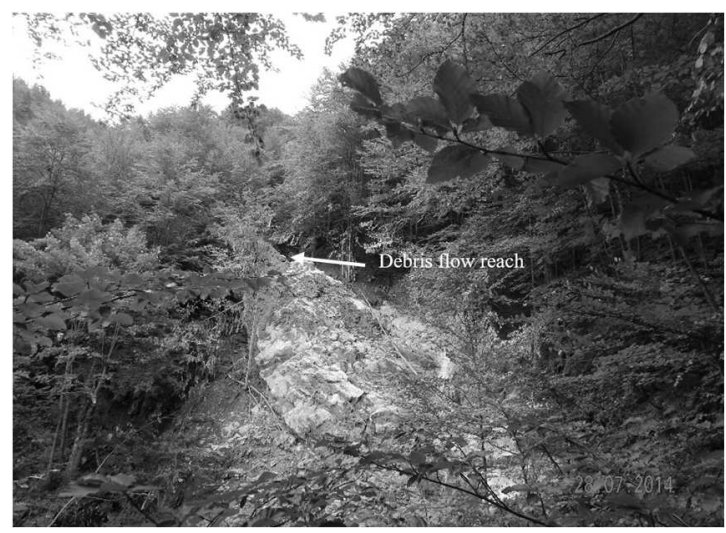

Fig. 6. Debris flow had a speed of several $\mathrm{m} \cdot \mathrm{s}^{-1}$

Arrow indicates maximum level of the flow.

A flow with a mixture composed of water-clay-stones continued down the narrow valley. It also absorbed bottom fills, which had accumulated in the previous period. From the tributaries joined similar, although smaller debris flows. Most of them eroded valleys down to the bedrock. Approximately at a distance of $560 \mathrm{~m}$ from the cable car station, 2 main debris flows joined together (funnel-like confluence, Figs. 7 and 10). Moreover, rocky debris was mobilized from the surrounding 
slopes that contributed to the material of the debris flows. In these parts of the area, rock falls of fragments and blocks likely occurred. On many trees that remained intact standing, fresh incisions were registered on the bark, undoubtedly the impacts of fragments and blocks (at a height of up to $2 \mathrm{~m}$ above the ground surface), which also contributed to the material of debris flows.

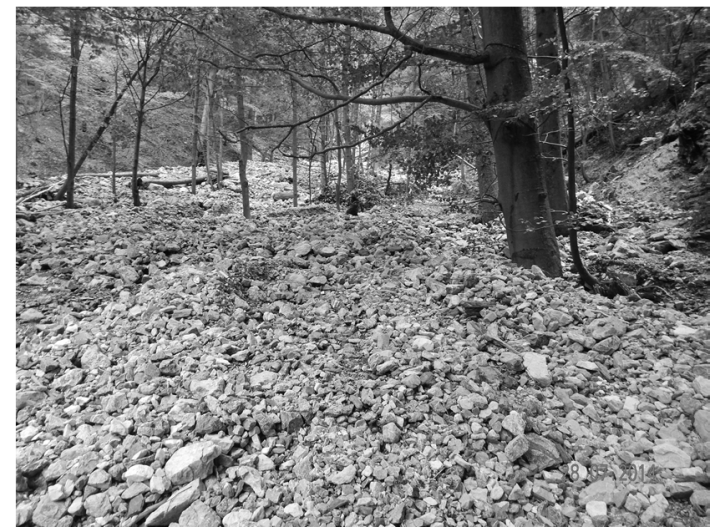

Fig. 7. One of the two of main debris flows

The total cubic capacity of the displaced material is estimated by the team of the State Geological Institute of Dionýz Štúr (SGIDŠ) at a minimum of $100,000 \mathrm{~m}^{3}$. The toe of the debris flow reached the cable line terminal (Fig. 8), which indeed experienced property damage, but without any serious static damage to buildings and lift poles. However, the catastrophe hit the cars at the car park or those along the road to Terchová (Fig. 9). The car passengers and the visitors managed to escape to the surrounding slopes, from where they observed the disastrous flow, taking everything, which crossed the way to the flood-wave.
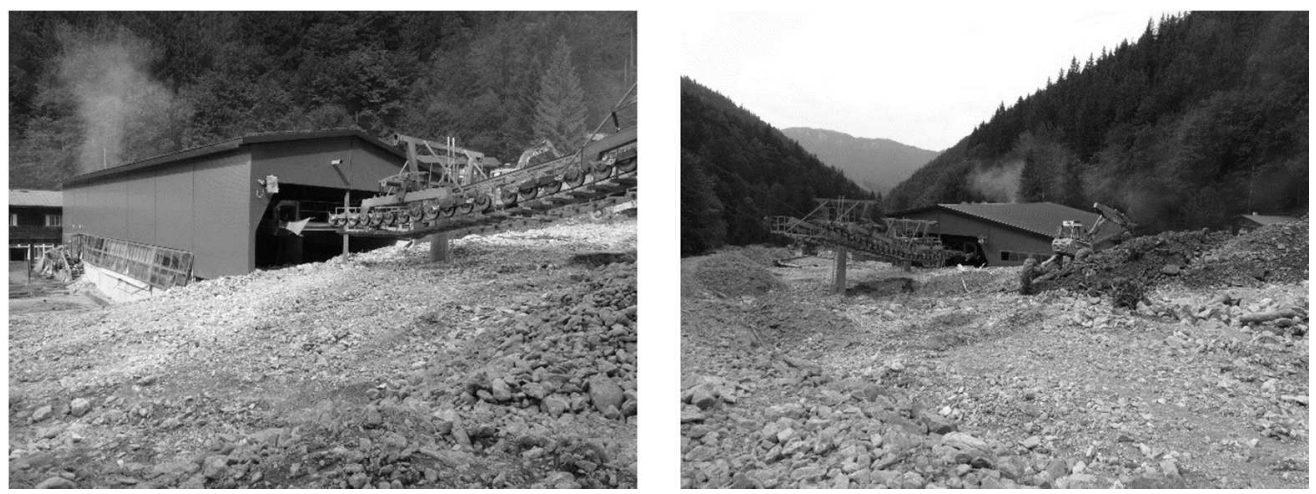

Fig. 8. Cable line terminal at the toe of the debris flow 


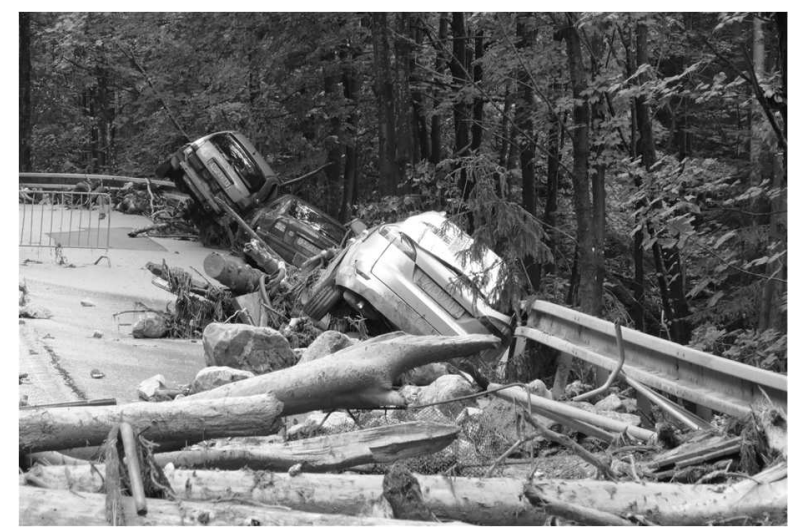

Fig. 9. Cars smashed by the debris flow

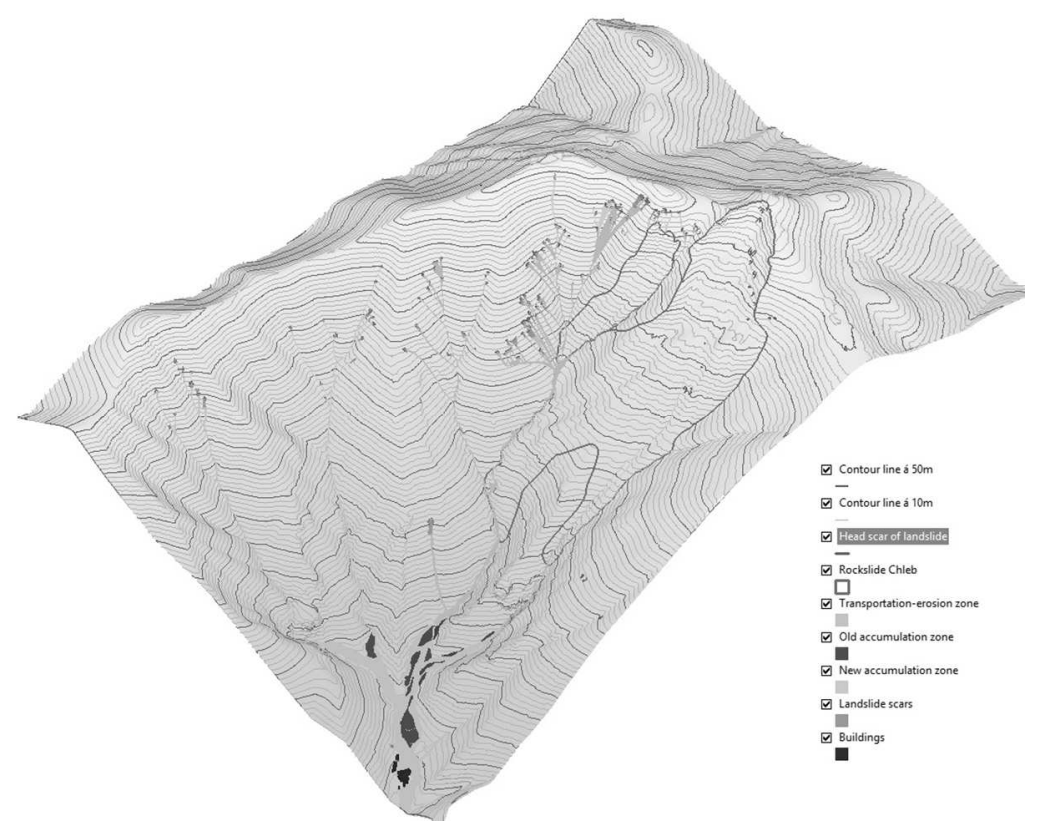

Fig. 10. DTM with slope failures in the Vrátna dolina Valley

\section{INPUT DATA AND MATERIALS}

Field research data collection was performed by several methods and technologies. At first, the staff of SGIDŠ carried out an engineering geological mapping of the resulting landslides and debris flows by the ground visual inspection with a GNSS recording. Another survey was performed by the LiDAR technology using airborne laser scanning. Simultaneously laser scanning along with high resolution aerial imagery was realised in a single flight. Lastly, ground control points for a LiDAR and photogrammetry processing were measured using global navigation satellite system (GNSS) instruments and geodetic total station (TS). 
The specificity of the task consisted mainly of a large height difference between the ridge parts and the valley, resulting in difficulties of a flight plan. The other problem (besides imagery) was the position of the valley in the northern flanks of the mountain range, resulting in great contrast and brightness (radiometric) differences between the slopes in shadows and the illuminated slopes (Fig. 12). Another problem was snow dust and icing in the northern upper part of area, that decreased the reflectance of the laser beam.

Field engineering geological mapping

Immediately after the landslide (July 28 - 30, 2014) the SGIDŠ staff carried out an engineering geological mapping of the resulting landslides and debris flows. They were in-situ surveyed by the GNSS system Trimble Geo 7X (H-Star) in RTK mode in SKPOS service with positional and vertical accuracy $\pm 0.10 \mathrm{~m}$. The source areas, the lithological composition, and the volumes of the debris flows along with the risk of their potential re-occurrence were assessed.

\section{Airborne laser scanning (November 23rd, 2014)}

Due to difficult to access terrain, the large area, high altitude differences and dense afforestation, the ALS technology has been selected for the detailed geomorphological documentation of the site. Prior to conducting the flight over the investigated area, a flight plan was created based on the nature of the area of interest and the requirements for the output data (in particular the accuracy of the data and the average density of the resulting point cloud). The data collection itself was carried out using the Seneca PA-34 aircraft carrier equipped with the Trimble Harrier 68i System for the advanced mapping of the corridors. The system consists of a fullwave laser scanner and a mid-format digital camera. It is designed for the creation of detailed LiDAR point clouds in combination with high quality georeferenced orthophoto mosaics. Aerial data collection was provided by the University of Žilina, Faculty of Operation and Economics of Transport and Communications, Department of Air Transport. The basic parameters of the laser scanner used are listed in Tab. 1.

Tab. 1. The main technical parameters of the used laser scanner

\begin{tabular}{lllc}
\hline Pulse repetition rate & $80 \mathrm{kHz}-400 \mathrm{kHz}$ & Vertical accuracy & $<0.15 \mathrm{~m}$ \\
Scan frequency & $10 \mathrm{~Hz}-200 \mathrm{~Hz}$ & Horizontal accuracy & $<0.25 \mathrm{~m}$ \\
Field of view & $45^{\circ}-60^{\circ}$ & Range resolution & $0.020 \mathrm{~m}$ \\
Operating altitude & $30-1,600 \mathrm{~m} \mathrm{AGL}$ & Intensity capture & $16 \mathrm{bit}$ \\
\hline
\end{tabular}

Together, 241,256,689 points were scanned within a $19 \mathrm{~km}^{2}$ area (Fig. 12, left part). A network of permanent GNSS stations of Slovak real-time positioning service (SkPOS) was used for the post-processing of the flight trajectory. The flight trajectory alignment along with the inertial measurement unit was implemented by POSPac software (Applanix). The relative accuracy of the aligned trajectory was not worse than $\pm 0.05 \mathrm{~m}$. Neighbouring cloud strips were adjusted by each other using overlap zones, and the combined cloud was then georeferenced and adjusted 
by the tools of the LPMaster software (Inpho/Trimble), vertically using control points (CP) and horizontally using control surfaces (roofs). The resulting vertical accuracy of the point cloud was reached by the value $\mathrm{mH}= \pm 0.20 \mathrm{~m}$, as evidenced by residual errors at the control points. The elevation range of the point cloud in the scanned area is 1,061m (646.8 m - 1,708.6 m a.s.1. - Vel'ký Kriváň Mt.). In further processing, the whole point cloud was classified into classes: ground, vegetation, and buildings. For this purpose, the SCOP++ and DTMaster (Inpho) software packages were used. The class ground then served as input data for DTM creation and contained 130,172,064 points with an average density of 5 points per $\mathrm{m}^{2}$ in forested areas and 12 points per $\mathrm{m}^{2}$ in opened ground surface. Final coordinate systems used were the ETRS89/TM 34N (with ellipsoidal heights h-ETRS89) but point cloud was saved into the national CRS: S-JTSK (Kronstadt sea gauge) too for archiving.

Overall 32 control points (CP's) were measured in the SkPOS network by the GNSS instruments Trimble R10 with an accuracy in position $\mathrm{mYX}=0.02 \mathrm{~m}$ and vertical accuracy $\mathrm{mH}=0.05 \mathrm{~m}$. Some points (which were not possible to measure by GNSS) were measured by tacheometry with a connection to the GNSS measurements. The control points were signalized by the padstones of the cable car poles (Fig. 11 left), the edges of newly built bridges, corners of roofs (Fig. 11 middle) or targets on the ridge pre-set in November, 2014 (Fig. 11, right part). Some CP's served for ALS point cloud adjustment, other for photogrammetric georeferencing and some for both.
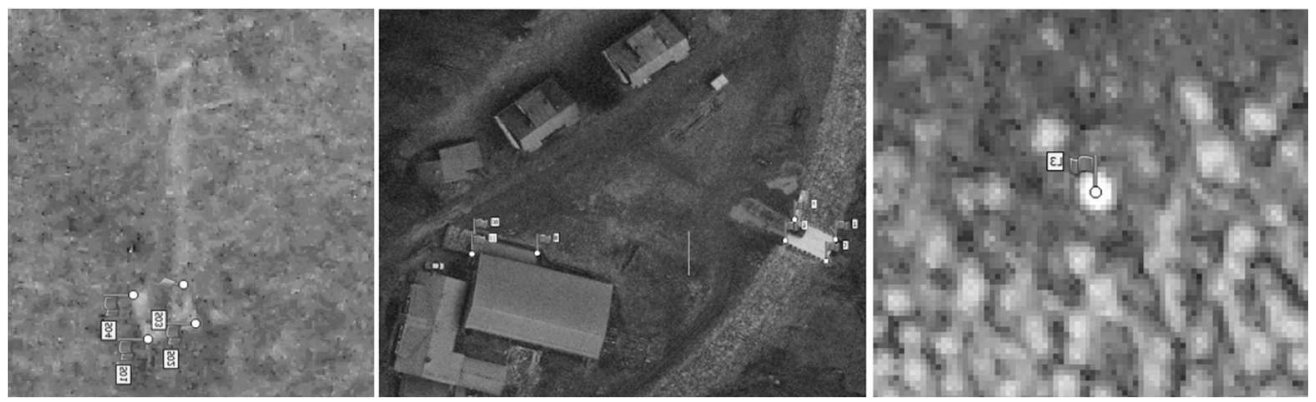

Fig. 11. Types of signalisation of the control points

From left: padstone of the pole, corners of the roofs and bridge and circle target on the terrain.

Photogrammetry (November 23rd, 2014)

Photogrammetric data was not necessary for required tasks but the system Harrier $68 \mathrm{i}$ allows simultaneous scanning and the taking of images during one flight. This is why we used it for the production of the orthophoto mosaic, which offered a detailed raster map in a high geometric resolution of the area of interest. The calibrated 60-megapixel Trimble AC P65 + middle format RGB digital camera was used for imagery (Tab. 2).

The flight strips were flown from the south to the north and east to west due to the high terrain elevation, thus excluding the possibility of empty spaces and holes. It also provided a higher point density per $\mathrm{m}^{2}$ of laser scanning. The forward overlap ranged from $60 \%$ on the ridge to $90 \%$ in the valley. The side overlap was from $50 \%$ on the ridge to $7 \%$ in the valley. Together 720 RGB images of the area stu- 
died were taken from a flight level of about 1,950 $\mathrm{m}$ a.s.l. (flight above ground level ranged from $1,250 \mathrm{~m}$ to $250 \mathrm{~m}$ ). The pixel size (GSD) on the ground ranged from $0.03 \mathrm{~m}$ on the ridge to $0.15 \mathrm{~m}$ in the valley. Image processing was done by the technology of the computer vision technique - Structure from Motion (SfM) in PhotoScan Pro software (Agisoft). The SfM method (e.g. Westoby et al. 2012) is based on the automatic detection of image features and its matching, automatic orientation of images to the image block and bundle block adjustment (with possibility of the camera self-calibration) using perspective transformation. The georeferencing was done using control points. The photogrammetric orientation results are presented in Tab. 3. The dense cloud of imaged surface, mesh and orthophoto mosaic were produced after photogrammetric orientations. The resulting orthophoto mosaic (Fig. 12) has geometric resolution $15 \mathrm{~cm} /$ pixel with an accuracy $\mathrm{mYX}=$ $\pm 0.17 \mathrm{~m}$ (1 sigma, normal probability distribution).

Tab. 2. The main technical parameters of the used camera

\begin{tabular}{llll}
\hline Resolution & $8,984 \times 6,732$ pixels & Data format & TIFF \\
Pixel size & $6 \times 6 \mu \mathrm{m}$ & Max shutter speed & $1 / 1,000 \mathrm{~s}$ \\
Focal length & $51 \mathrm{~mm}$ & Radiometric res. & $16 \mathrm{bit}$ \\
Field of view & $54^{\circ} \times 43^{\circ}$ & Spectral bands & RGB + NIR \\
\hline
\end{tabular}

Tab. 3. The results of photogrammetric orientations

\begin{tabular}{|c|c|c|c|}
\hline $\begin{array}{l}\text { Control points residuals }(32 \mathrm{CP}) \\
\text { Overall } R M S\end{array}$ & $\mathrm{Y}=0.06 \mathrm{~m}$ & $\mathrm{X}=0.08 \mathrm{~m}$ & $\mathrm{H}=0.17 \mathrm{~m}$ \\
\hline $\begin{array}{l}\text { Control points residuals }(32 \mathrm{CP}) \\
\text { Max. }\end{array}$ & $\mathrm{Y}=0.19 \mathrm{~m}$ & $\mathrm{X}=0.20 \mathrm{~m}$ & $\mathrm{H}=0.27 \mathrm{~m}$ \\
\hline $\begin{array}{l}\text { Image residuals (all tie points) } \\
\text { Overall } R M S\end{array}$ & 0.532 pix & & \\
\hline Number of the tie points & $2,391,410$ & & \\
\hline Average number of rays on the tie points & 3.5 & & \\
\hline
\end{tabular}
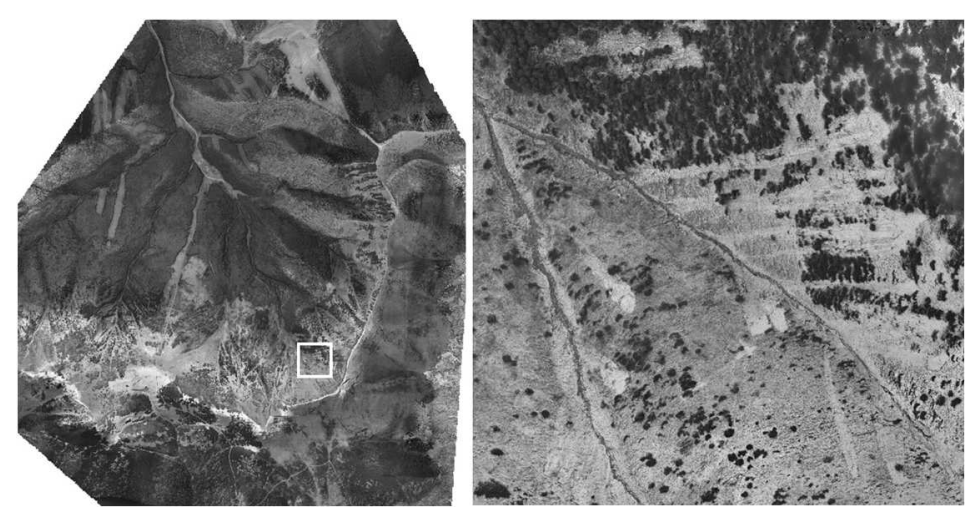

Fig. 12. Whole orthophoto mosaic (left) and detail (right) 


\section{MORPHOMETRIC DETECTION OF THE SLOPE FAILURES}

The Proxima technology has been used to identify areas with slope deformations (landslides). This technology combines a number of calculation processes.

Initially, according to theories on surface analysis available in differential geometry, the so called Dupin's indicatrix (Dupin 1813) is calculated at every single point of a digital surface. Dupin's indicatrix is a key descriptor of surface properties such as slope, aspect, Gaussian curvature, slopeline curvature, tangential curvature and extreme curvatures (Krcho 2001).

Proxima system (Fig. 15) uses this descriptor as classifier of all surface points. For example elliptical concave, elliptical convex and hyperbolical points, defined by the Dupin's indicatrix shape, form three basic categories of surface shape (Fig. $13)$.

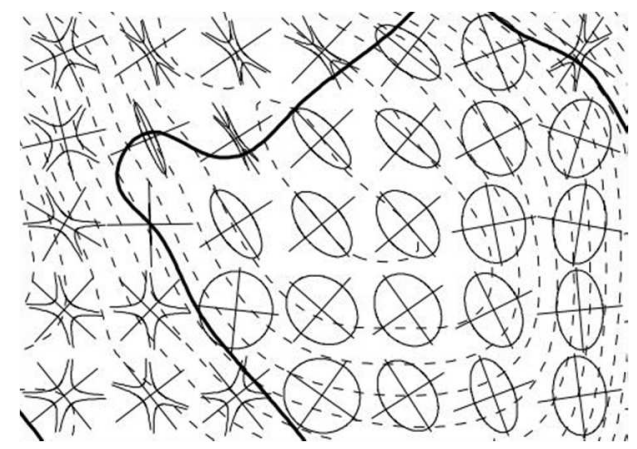

Fig. 13. Areas of elliptical and hyperbolical points are delineated and Dupin's indicatrices are drawn at every point of a surface (Dirstein et al. 2013 and Geoproxima 2019)

The following morphometric properties defined by Dupin's indicatrix are used to create spatial polygonal and linear objects as connected areas: slope, aspect, normal curvature in the direction of slopelines, normal curvature in the direction of contour lines, discriminant of the second Gaussian differential form, Gaussian curvature and Mean curvature. Categorized objects are then inserted into the spatial database and next a processing step is performed in order to calculate and assign more geometric, and morphometric properties to every single spatial object. Shape properties of the spatial objects such as eccentricity, symmetry or complexity are calculated (Krcho 1990 and Costa et al. 2009). A spatial database allows the very efficient use of spatial and attribute queries to filter objects with properties required by the interpretation process.

A database of morphometric properties can be constructed at various levels of detail. The level of detail is similar to window size when calculating surface properties using other methods such as Wood (1996). Selecting a specific level of detail is important when interpreting results and depends on the particular application. A small level of detail in general captures very detailed shapes of the surface meanwhile a high level of detail provides higher generalization and captures only significant shapes (Fig. 14).

An example of such specific interpretation requirements is morphometric analysis and the interpretation of LiDAR data in archaeology where very subtle convex objects delineate the possible location of old burial places (Pašteka et al. 2017). 


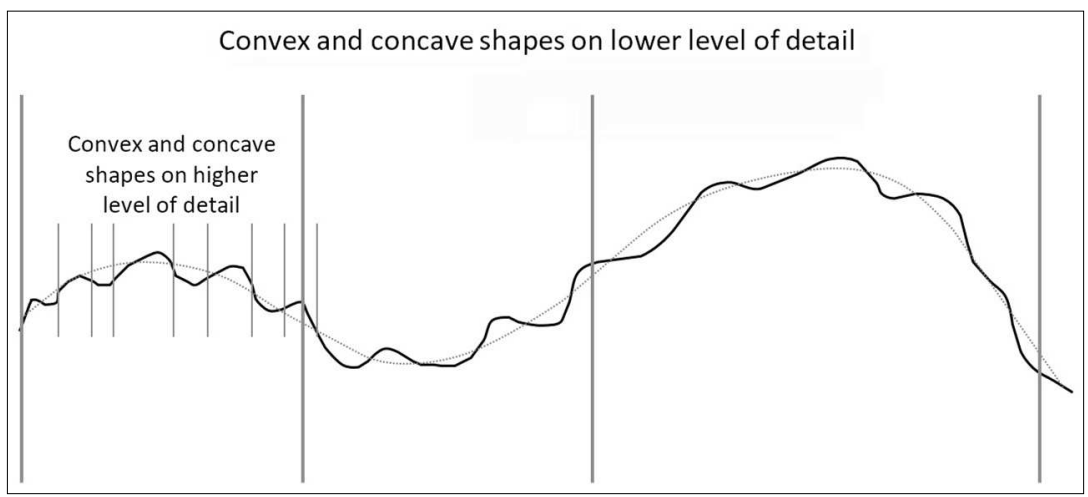

Fig. 14. Example of profile curve divided to convex and concave shapes on two levels of detail

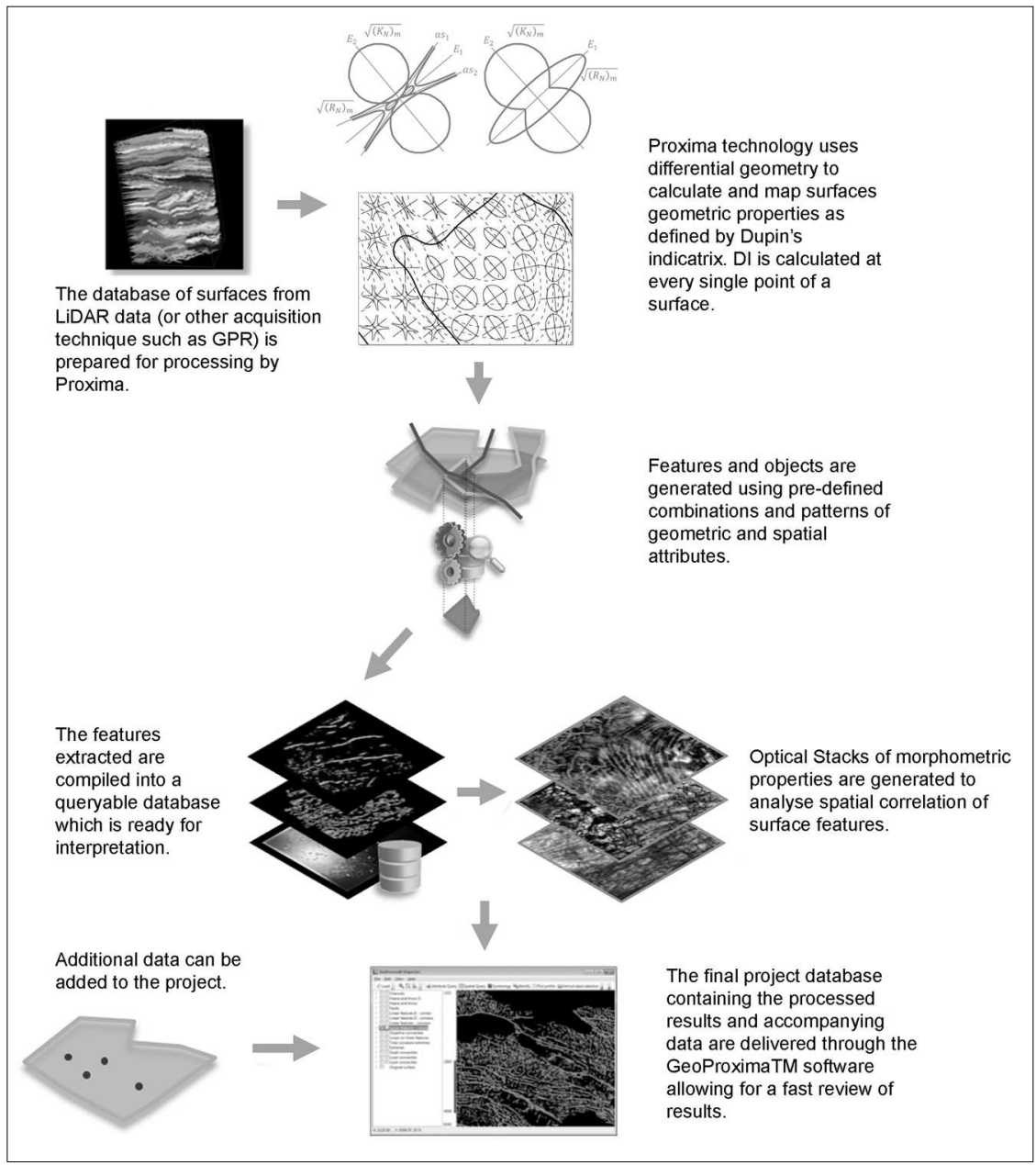

Fig. 15. Schematic representation of the Proxima processing procedure (Pašteka et al. 2015) 
In order to obtain high quality results, it is necessary to work with a digital terrain model of the highest precision possible. For this reason, the DTM obtained from airborne laser scanning is a very good basis for this type of analysis.

\section{RESULTS AND DISCUSSION}

The verification of the results in the monitored area was carried out by comparing them with the data obtained from the field survey. Four locations with the occurrence of active slope failures recorded were identified for the evaluation of the results. Three of these sites are located at the top of the slope near the Hromové Mt. (Figs. 1 and 5). One site is located in the central part of the slope and is characterized by a higher level of afforestation compared to other localities. The location of individual sites is shown in Fig. 1.

In the location 1 (Fig. 16), the field measurements were focused on seven active slope failures with a surface area of $34-263 \mathrm{~m}^{2}$. The results of the comparison of the in-situ measured data with the data obtained by the Proxima procedure suggest that the identification has succeeded in capturing the slope deformations in high precision (Tab. 4). In a visual comparison, it is possible to see consistency in the spatial location but also in the head scarp areas of the landslides. The areas of identified landslides using the Proxima technology are slightly underestimated in comparison with the surveyed data.

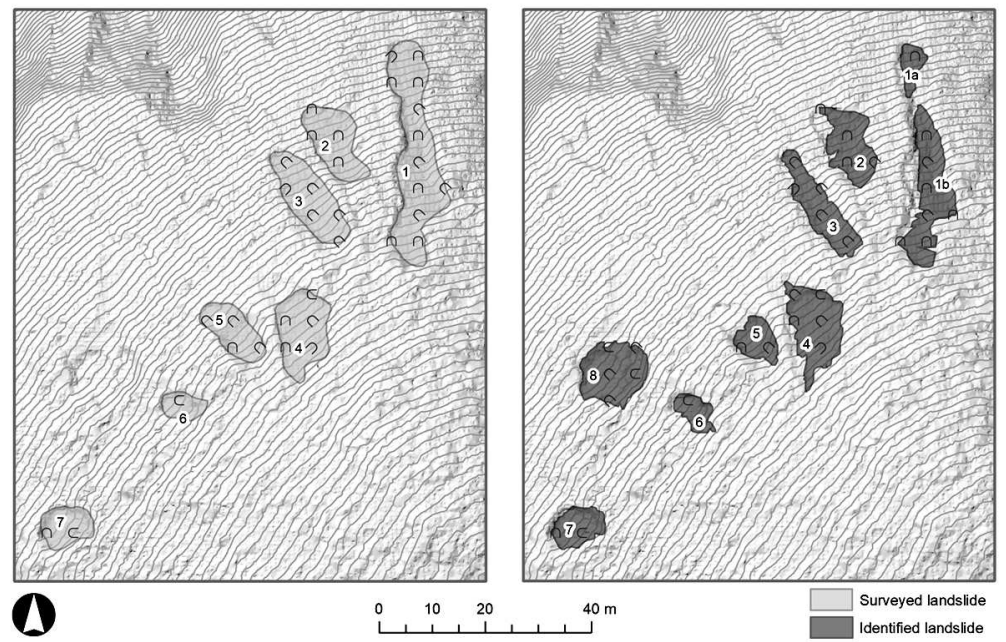

Fig. 16. Surveyed (left) and numerically detected landslides (right) in the location 1 (see Fig. 1)

In the location 2 (Fig. 17), three relatively larger landslides were identified in the field. One of these slides (no. 1) reaches area of $965 \mathrm{~m}^{2}$. The calculated result does not show this large scroll as a whole, but it divides it into two smaller flat landslides, which is obviously caused by the different level of the detected detail than by the measurement in the field. The same situation can be observed for another landslide in this area (no. 3). Despite this fact, the used algorithm captured the real state with a relatively good accuracy (Tab. 5). 
Tab. 4. Comparison of the surveyed and numerically detected landslide areas in location 1

\begin{tabular}{ccc}
\hline Landslide identification & Surveyed area $\left(\mathrm{m}^{2}\right)$ & Identified area $\left(\mathrm{m}^{2}\right)$ \\
\hline 1 & 263.12 & 170.00 \\
2 & 106.38 & 94.39 \\
3 & 131.77 & 101.37 \\
4 & 126.00 & 129.24 \\
5 & 81.00 & 48.51 \\
6 & 34.19 & 34.79 \\
7 & 61.82 & 57.01 \\
8 & - & 117.83 \\
Total & 804.28 & 753.14 \\
\hline
\end{tabular}
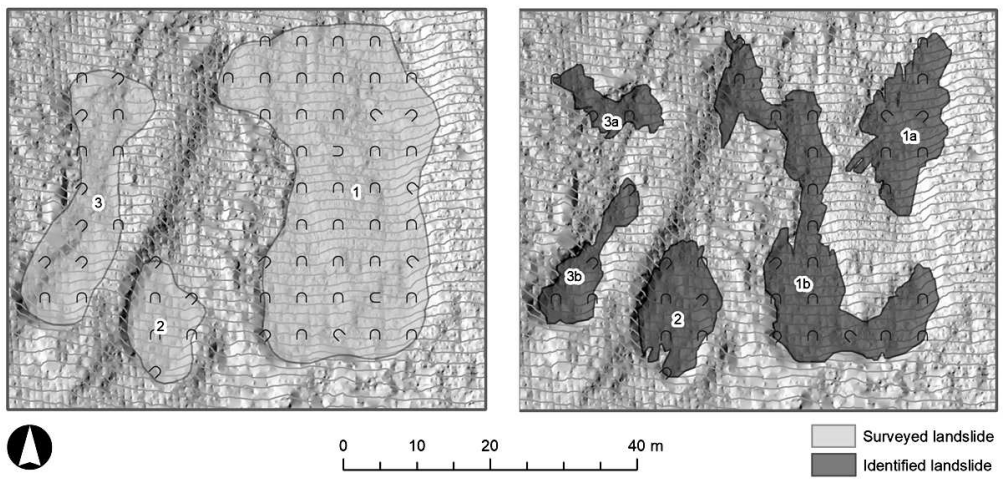

Fig. 17. Surveyed (left) and numerically detected landslides (right) in location 2 (see Fig. 1)

Tab. 5. Comparison of the surveyed and numerically detected landslide areas in location 2

\begin{tabular}{ccc}
\hline Landslide identification & Surveyed area $\left(\mathrm{m}^{2}\right)$ & Identified area $\left(\mathrm{m}^{2}\right)$ \\
\hline 1 & 964.52 & 570.22 \\
2 & 121.15 & 137.55 \\
3 & 293.50 & 150.06 \\
Total & $1,379.17$ & 857.83 \\
\hline
\end{tabular}

In the location 3 (Fig. 18), which is also located at the top of the slope, the terrain measurements have identified 4 active landslides, or separated areas of debris flow. Their area ranges from 114 to $244 \mathrm{~m}^{2}$. The results at this location also prove the suitability of the Proxima procedure to identify slope deformations (Tab. 6). The detection succeeded in capturing all the field-surveyed landslides. In addition, one smaller slope deformation, located in the centre of the site, was identified (no. 5). Its occurrence will be verified in the next stage of the field survey. 


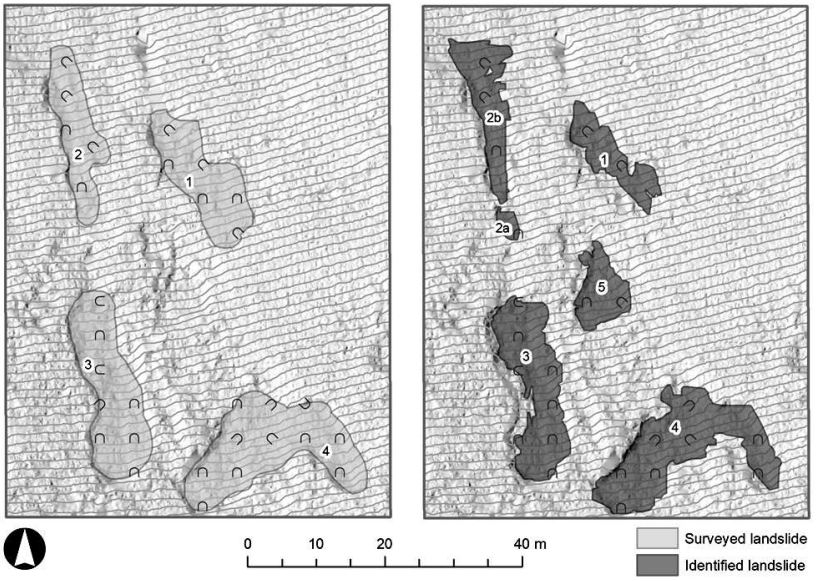

Fig. 18. Surveyed (left) and numerically detected landslides (right) in location 3 (see Fig. 1)

Tab. 6. Comparison of the surveyed and numerically detected landslide areas in location 3

\begin{tabular}{ccc}
\hline Landslide identification & Surveyed area $\left(\mathrm{m}^{2}\right)$ & Identified area $\left(\mathrm{m}^{2}\right)$ \\
\hline 1 & 143.36 & 72.29 \\
2 & 113.81 & 106.78 \\
3 & 189.47 & 163.75 \\
4 & 243.68 & 217.07 \\
5 & - & 62.92 \\
Total & 690.32 & 622.81 \\
\hline
\end{tabular}

Location 4 (Fig. 19), located in the central part of the slope, is characterized by a higher degree of afforestation than was the case of the previous three sites. This fact also influenced the arrangement of the slope deformations. Where the forest stands, the development of slope failures in this area was moderated. Nevertheless, the field measurements confirmed the presence of several active slides with an area ranging from 36 to $753 \mathrm{~m}^{2}$. The application of the Proxima technology over the digital terrain model has enabled the identification of terrain-surveyed landslides (Fig 19 and Tab. 7). In some cases, the higher level of detail has again led to the separation of the numerically identified landslides into multiple areas (area no. 3 into areas 3a, b, c, no 6 into 6a, b, c-Fig. 19) In addition, the algorithm identified the additional slope deformations that were not recorded during the survey, for instance due to inaccessible landscapes (areas no. 10, 11). 


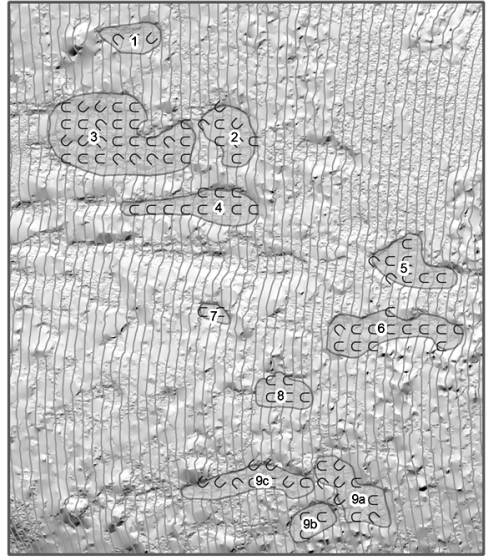

$\boldsymbol{\Delta}$

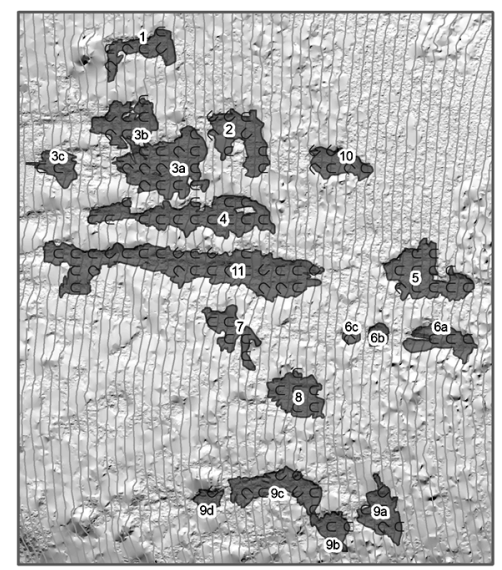

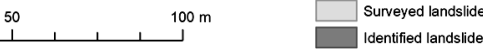

Fig. 19. Surveyed (left) and numerically detected landslides (right) in location 4 (see Fig. 1)

Tab. 7. Comparison of the surveyed and numerically detected landslide areas in location 4

\begin{tabular}{ccc}
\hline Landslide identification & Surveyed area $\left(\mathrm{m}^{2}\right)$ & Identified area $\left(\mathrm{m}^{2}\right)$ \\
\hline 1 & 122.98 & 119.52 \\
2 & 197.35 & 191.03 \\
3 & 752.86 & 573.44 \\
4 & 255.92 & 339.31 \\
5 & 225.74 & 239.07 \\
6 & 333.64 & 174.28 \\
7 & 36.12 & 118.21 \\
8 & 133.34 & 154.99 \\
9 & 575.06 & 418.42 \\
10 & - & 104.31 \\
11 & - & 680.06 \\
Total & $2,633.01$ & $3,112.62$ \\
\hline
\end{tabular}

\section{CONCLUSIONS}

The article deals with the mapping of the slope deformations in the Vrátna dolina Valley in the northern part of Slovakia. The slope failures evolved in July 21, 2014 due to precipitation extremes. The Proxima technology was used for the analytical detection of the landslides and data from the airborne laser scanning and photogrammetry were used as the source data. As the territory is in a badly accessible terraine, the use of remote sensing methods is very helpful in this kind of areas. Furthermore, in addition to the high accuracy and level of detail of the ALS data, it is also an advantage that the technology enables to capture the Earth's surface even 
under forest cover. The detection of the slope failures was carried out in four locations. The results were compared with the data obtained from the field survey and measurements. Additional orthophoto mosaics were used as supplementary data for evaluation of the results in open areas.

The results show considerable accuracy when compared to the data obtained from the field survey. In all the studied localities, high-quality detection of the slope deformations occurrences has been reached. In some cases, slope failures not recorded in the terrain during the field survey (the locations 3 and 4) have also been identified. This data will be reassessed in the next phase of the field survey. The level of detail of the results themselves, which needs to be adapted to the project objectives, was a very important factor in evaluating the results.

This article was supported by ITMS 26220220156 "Brokerage Centre of Air Transport for Transfer of Technology and Knowledge into Transport and Transport Infrastructure.

\section{REFERENCES}

ARDIZZONE, F., CARDINALI, M., GALLI, M., GUZZETTI, F., REICHENBACH, P. (2007). Identification and mapping of recent rainfall-induced landslides using elevation data collected by airborne Lidar. Natural Hazards and Earth System Science, Copernicus Publications on behalf of the European Geosciences Union, 7, 637-650.

BALIAK, F., NEMČOK, A., PAŠEK, J. (1981). Svahové deformácie v Krivánskej Malej Fatre. In Janík, M., Stollmann, A., eds. Rozsutec. Štátna prírodná rezervácia. Martin (Osveta). pp. 126-142.

BOBAL, P., SIPINA, S, ŠKULKÉTY, F. (2017). Aspect of arial laser scanning when exploring unknown archeological sites. Transportation Research Procedia, 28, 37-44.

BOLLMANN, E., SAILER, R., BRIESE, C., STÖTTER, J., FRITZMANN, P. (2011). Potential of airborne laser scanning for geomorphologic feature and process detection and quantifications in high alpine mountains. Geomorphologie Supplementary, Supplementary Isues. 55, 83-104. DOI: 10.1127/0372-8854/2011/0055S2-0047.

COSTA, L., CESAR, Jr., R., LAPLANTA, P., (2009). Shape classification and analysis. Boca Raton (CRC Press). DOI: 10.1201/9781315222325.

DIRSTEIN, J., HRONČEK, S., IHRING, P. (2013). Digital surface analysis: a completely new approach using differential geometry. In 23rd Geophysical Conference and Exhibition. Melbourne, 11. - 14. August 2013. Clayton (Csiro Publishing), pp. 1-4. DOI:10.1071/ASEG2013ab154.

DŁUGOSZ, M. (2012). Digital terrain model (DTM) as a tool for landslide investigation in the Polish Carpathians. Studia Geomorhologica Carpatho-Balcanica, 46, 5-23. DOI: 10.2478/v10302-012-0001-3.

DUPIN, Ch. (1813). Développements de Géométrie. Paris (Courcier).

GONZẢLEZ-DÍEZ, A., FERNÁNDEZ-MAROTO, G., DOUGHTY, M. W., DÍAZ DE TERÁN, J. R., BRUSCHI, V. M., CARDENAL, J., PÉREZ-GARCÍA, J. L., MATA, E., DELGADO, J., (2013). Development of a methodological approach for the accurate measurement of slope changes due to landslides, using digital photogrammetry. Landslides, 11(4), 1-14. DOI: 10.1007/s10346-013-0413-5.

GEOPROXIMA. (2019). A utomated surface analysis and geodatabase creation, [Online]. Available: https://www.geoproxima.sk/wp-content/uploads/2016/06/Proxima_ Overview.pdf [accessed: 14 March 2018].

HONKAVAARA, E., LITKEY, P., NURMINEN, K. (2013). Automatic storm damage detection in forests using high altitude photogrammetric imagery. Remote Sensing, 5, 1405-1424. DOI: $10.3390 /$ rs5031405. 
JABOYEDOFF, M., OPPIKOFER, T., ABELLÀN, A., DERRON, M. H., LOYE, A., METZGER, R., PEDRAZZINI, A. (2010). Use of LIDAR in landslide investigations: a review. Natural Hazards, 61, 5-28. DOI: 10.1007/s11069-010-9634-2.

KRCHO, J. (1990). Morfometrická analýza a digitálne modely georeliéfu. Bratislava (Veda).

KRCHO, J. (2001). Modelling of georelief and its geometrical structure using DTM: positional and numerical accuracy. Bratislava (Q111).

LIOVÁ, S., ZVOLENSKÝ, M., PETRÁŠEK, M. (2015). Natural disaster in Vrátna dolina on July 21, 2014. Manažment povodi a povodñových rizík 2015 a Hydrologické dni 2015. [elektronický zdroj]: spoločné vedecké podujatie s medzinárodnou účastou. Bratislava, 6. - 8. 10. 2015. Bratislava (MŽP SR), CD-ROM.

MITÁŠOVÁ, H., HOFIERKA, J. (1993) Interpolation by regularised spline with tension: II. Application to terrain modeling and surface geometry analysis. Mathematical Geology, 25,657-669. DOI: 10.1007/BF00893172.

NEMCOK, A. (1973). Genéza chlebských kotlov a jej význam pre uskutočnenie objektov Smerného územného plánu vo Vrátnej. Bratislava (Archive of Geofond).

PAŠTEKA, R., HRONCEK, S., FELCAN, M., MILO, P., WILKEN, D., PUTIŠKA R., (2017). A new semi-automated interpretation of concave and convex features in digital archaeogeophysical datasets. In Jennings, B., Gaffney, Ch., Sparrow, T., Gaffney, S., eds. International Conference of Archaeological Prospection. 12. ed. Oxford (The University of Bradford; Archeopress Archaeology), pp. 183-185.

PAŠTEKA, R., HRONČEK, S., IHRING, P., BOSANSKY, M., PUTIŠKA, R. (2015). Concave and convex features analysis of Bouguer gravity field with following qualitative interpretation. Paper presented at the 77th EA GE Conference and Exhibition 2015, EAGE, June, 2015.

PAVELKA K., ŠEDINA, J. (2015). Creating of DSM based on RPAS measurement and accuracy testing. In Růžičková K., Inspektor T., eds. Surface models for geosciences. lecture notes in geoinformation and cartography. Cham (Springer). DOI: 10.1007/9783-319-18407-4 15. pp 173-188.

PFEIFER, N., STĀDLER, P., BRIESE, C. (2001). Derivation of digital terrain models in the SCOP++ environment. Proceedings of OEEPE Workshop on Airborne Laser scanning and Interferometric SAR for Detailed Digital Terrain Models. Stockholm, 1.-3. March 2001. Stockholm (Royal Institute of Technology). Unpaginated.

RAZAK, K. A., STRAATSMA, M. W., WESTEN, C. J., MALET, J. P., JONG, S. M. (2011). Airborne laser scanning of forested landslides characterization: terrain model quality and visualisation. Geomorphology, 126, 186-200. DOI: 10.1016/j.geomorph. 2010.11.003.

ROBERTS, A. (2001). Curvature attributes and their application to 3D interpreted horizons. First Break, 19, 85-100. DOI: 10.1046/j.0263-5046.2001.00142.x.

SHAN, J., TOTH, C. K. (2009). Topographic laser ranging and scanning: principles and processing. Boca Raton (CRC Press/Taylor \& Francis Group).

SCHRAML, K., THOMSCHITZ, B., McARDELL, B. W., GRAF, C., KAITNA, R. (2015). Modelling debris-flow runout patterns on two alpine fans with different dynamic simulation models. Natural Hazards and Earth System Science, 15, 1483-1492. DOI: 10.5194/nhess-15-1483-2015.

VASTARANTA, M., WULDER, M. A., WHITE, J. C., PEKKARINEN, A., TUOMINEN, S., GINZLER, C., KANKARE, V., HOLOPAINEN, M., HYYPPÄ, J., HYYPPÄ, H. (2013). Airborne laser scanning and digital stereo imagery measures of forest structure: comparative results and implications to forest mapping and inventory update. Canadian Journal of Remote Sensing, 39, 382-395. DOI: 10.5589/m13-046.

VOSSELMAN, G., MAAS, H. G. (2010). A irborne and terrestrial laser scanning. Dunbeath (Whittles). 
WESTOBY, M. J., BRASINGTON, J., GLASSER, N. F., HAMBREY, M. J., REYNOLDS, J. M. (2012).'Structure-from-Motion' photogrammetry: a low-cost, effective tool for geoscience applications. Geomorphology, 179, 300-314. DOI: 10.1016/ j.geomorph.2012.08.021.

WHiTE, J. C., WUlder, M. A., VASTARANTA, M., COOPS, N. C., PITT, D., WOODS, M. (2013). The utility of image-based point clouds for forest inventory: a comparison with airborne laser scanning. Forests, 4, 518-536. DOI: 10.3390/f4030518.

WOOD, J. (1996). The geomorphological characterisation of digital elevations models. Ph.D. Thesis, University of Leicester, UK.

Marek Fra štia, Pavel Liščák, Andrej Žilka, Peter Paudit š, Peter Bobál, Stano Hronček, Slavomír Sipina, Pavol Ihring, Marián Mar či ̌s

\section{MAPOVANIE HLINITO-KAMENITÝCH PRÚDOV MORFOMETRICKOU ANALÝZOU DMR: PRÍPADOVÁ ŠTÚDIA VRÁTNA DOLINA, SLOVENSKO}

Príspevok sa zaoberá mapovaním svahových procesov v oblasti Vrátnej doliny nachádzajúcej sa na strednom Slovensku. V tejto oblasti došlo v roku 2014 vplyvom extrémnych zrážkových udalostí k výskytu svahových deformácií, ktoré spôsobili v záujmovom území značné škody.

$\mathrm{Na}$ analytickú detekciu zosuvov bola použitá technológia Proxima, pričom ako zdrojové dáta slúžili údaje leteckého laserového skenovania a fotogrametrie. Vzhl'adom na náročné terénne podmienky sme využili metódy dial'kového prieskumu, čo sa v danom type terénu ukázalo ako vel'mi výhodné. Letecké laserové skenovanie má oproti fotogrametrii vel'kú výhodu v tom, že dokáže zaznamenávat' informácie aj o teréne nachádzajúcom sa pod vegetáciou. Okrem toho bolo spoločne s laserovým skenovaním realizované aj letecké snímkovanie, z ktorého boli neskôr ortofotomozaiky využité ako podporné údaje pri zhodnotení výsledkov. Laserové skenovanie dosiahlo priemernú hustotu až 16 bodov $/ \mathrm{m}^{2}$, ortofotomozaika bola vyhotovená vo výslednom rozlíšení $0,15 \mathrm{~m}$. Analytická detekcia svahových procesov sa realizovala použitím technológie Proxima v štyroch lokalitách vopred identifikovaných v záujmovej oblasti. Technológia poskytuje na výstupe kompletný súbor morfometrických veličín popisujúcich povrch terénu v rôznej úrovni detailu. Pomocou nich je možné identifikovat' v pozorovanej oblasti konkrétne terénne prvky. Aby sa dala overit' presnost' mapovania zosuvov, bol v území vykonaný podrobný terénny geologický prieskum realizovaný pracovníkmi Státneho geologického ústavu Dionýza Štúra.

Výsledky mapovania poukázali na vhodnost' technológie Proxima pri detekcii svahových deformácií. Vo všetkých štyroch lokalitách došlo $\mathrm{k}$ vysokej korelácii medzi údajmi meranými v teréne a Proximou detegovanými údajmi. Technológia dokonca umožnila identifikovat' na laserovom mračne bodov niekol'ko d'alších menších zosuvov, ktoré neboli pomocou terénneho prieskumu objavené. Vel'mi dôležitým parametrom pri vyhodnocovaní výsledkov modelovania aplikovanou technológiou je úroveň detailu. Ked’že použitá technológia dokáže poskytnút' výsledky v rôznych úrovniach detailu, výber vhodnej úrovne je potrebné dôkladne zvážit' podl'a samotných ciel'ov projektu. 